\title{
ANALISIS FAKTOR-FAKTOR YANG MEMPENGARUHI PERMINTAAN TEMPE DI KELURAHAN JURANGMANGU TIMUR, PONDOK AREN, TANGERANG SELATAN
}

\author{
Fachrul Imam Hanafi*, Edmon Daris**, Siti Rochaeni**
}

\begin{abstract}
ABSTRAK
Tujuan penelitian ini adalah mengetahui karakteristik masyarakat yang mengkonsumsi tempe di Kelurahan Jurangmangu Timur, mengetahui faktor-faktor yang mempengaruhi permintaan tempe di Kelurahan Jurangmangu Timur, mengukur besarnya respon masyarakat terhadap perubahan harga tempe di Kelurahan Jurangmangu Timur. Jenis dan sumber data yang digunakan peneliti adalah data primer yang diperoleh dari penyebaran kuisioner kepada masyarakat setempat, dan data sekunder diperoleh dari pemerintah daerah setempat dan literatur-literatur seperti; jurnal, buku-buku yang relevan dan artikel yang berhubungan dengan penelitian. Dalam pengambilan sampel peneliti menggunakan metode purposive random. Metode analisis yang digunakan peneliti adalah analisis regresi linier berganda dengan bantuan SPSS. Kesimpulan dari faktor-faktor tersebut secara bersama-sama dapat dikatakan berpengaruh terhadap permintaan tempe di kelurahan Jurangmangu Timur. Hasil perhitungan elastisitas harga tempe di dapat sebesar 0.970, artinya tempe bersifat inelastis. Dalam jangka pendek Permintaan tempe bersifat inelastis terhadap semua faktor-faktor yang mempengaruhi permintaan tempe dan pendapatan keluarga tidak berpengaruh besar terhadap perubahan permintaan. Saran yang dapat di tarik dari hasil perhitungan regresi yang menyatakan bahwa harga tempe sangat berpengaruh nyata terhadap permintaan tempe di kelurahan Jurangmangu Timur, sehingga produsen tempe yang ada dapat meningkatkan kapasitas produksi tempe untuk memenuhi kebutuhan tempa masyarakat di kelurahan Jurangmangu Timur. Penelitian ini membahas mengenai elastisitas permintaan jangka pendek, diharapkan ada penelitian lanjutan mengenai elastisitas permintaan jangka panjang terhadap faktor-faktor harga tempe, tahu, telur, dan jumlah anggota keluarga, serta pendapatan keluarga.
\end{abstract}

Kata kunci : analisis faktor, permintaan tempe 


\begin{abstract}
The purpose of this study is to determine characteristics of people who consume tempe at the East Jurangmangu village, to determine factors that affect the demand for soybean in the East Jurangmangu village, to measure the amount of public response to the changes in the price of tempe at the East Jurangmangu village. The types and sources of data used by researchers are the primary data that are obtained from the questionnaire from the local community, and secondary data are obtained from the local government and literature such as; journals, relevant books and articles related to the research. Sampling method is done by using purposive random sampling. The analytical method used uses multiple linear regression analysis by using SPSS. The conclusion is all the factors affect the demand for soybean in East Jurangmangu village. The results of calculation of price elasticity show that tempe has an elasticity of 0.970 meaning that tempe is inelastic. In the short term, tempe Demand is inelastic to all the factors that influence the demand for soybean and family income does not greatly affect changes in demand. We suggest that price of tempe has a very real impact on demand in the Jurangmangu East village, so the existing tempe producers can increase soybean production capacity to meet the needs of the people in the Jurangmangu East village. This study discusses the elasticity of demand only for short-term, there is expected to further research on the long-term demand elasticity to price factors of tempe, tofu, eggs, and the number of family members, as well as family income.
\end{abstract}

Keywords: factor analysis, demand of tempe

\section{PENDAHULUAN}

Tempe merupakan makanan asli Indonesia yang telah dikonsumsi selama berabad-abad. Dari segi nilai sosial pangan, tempe pada beberapa tahun sebelum era orde baru termasuk kedalam makanan inferior akibat ungkapan-ungkapan ironis atau sindiran, seperti "jangan menjadi bangsa tempe" melahirkan kesan bahwa masyarakat pemakan tempe adalah masyarakat rendahan, lemah semangat juang dan tidak modern. Tempe menjadi makanan khas Indonesia yang masih bertahan hingga saat ini, bahkan sudah menjadi lauk andalan keluarga Indonesia.

Masyarakat sebagai sumberdaya manusia memerlukan konsumsi pangan yang baik untuk memenuhi kecukupan gizi yang diperlukan dalam proses pertumbuhan. Konsumsi bahan pangan masyarakat sehari-hari hendaknya memenuhi dua kriteria kecukupan gizi, yaitu kecukupan kalori dan protein. Kebutuhan kalori biasanya diperoleh dari konsumsi makanan pokok (karbohidrat). Sementara kebutuhan protein diperoleh dari makanan yang berasal dari tumbuhtumbuhan (protein nabati) dan hewan 
(protein hewani).

Komposisi gizi tempe baik kadar protein, lemak, dan karbohidratnya tidak banyak berubah dibandingkan dengan kedelai. Namun, karena adanya enzim pencernaan yang dihasilkan oleh kapang tempe, maka protein, lemak, dan karbohidrat pada tempe menjadi lebih mudah dicerna, diserap, dan dimanfaatkan tubuh dibandingkan yang terdapat dalam kedelai.

Menurut Shurtleff dan Aoyagi (1976) dengan menggunakan penilaian kualitas protein yang dinyatakan dalam PER (Protein Efficient Ratio) yang merupakan Nisbah Keefisienan Protein yang digunakan tubuh untuk pertumbuhan dengan standar referensi yaitu PER kasein sebesar 2,5 sebagai pembanding, didapatkan angka PER tempe kedelai dan gandum sebesar 2,79. Angka yang lebih tinggi daripada telur, semua daging, dan seluruh dairy Product kecuali susu. Disamping itu, tempe merupakan "Complete Protein" yang mengandung delapan (atau sepuluh termasuk sistin dan tirosin) asam amino esensial yang membangun gugus protein dan display ke dalam tubuh.

Kelurahan Jurangmangu Timur adalah salah satu kelurahan di kecamatan Pondok Aren Tangerang Selatan yang

$$
\text { masyarakatnya beraneka ragam }
$$
menurut usia, pendapatan, dan tingkat pendidikannya. Jurangmangu timur memiliki jumlah penduduk yang padat dengan tingkat penghasilan menengah ke bawah. Mengingat potensi tempe sebagai sumber makanan yang bergizi dan memiliki banyak manfaat lainnya serta kebutuhan masyarakat akan sumber protein, maka mendorong penulis untuk mengkaji dan menganalisis faktor-faktor yang mempengaruhi permintaan tempe yang ada di kelurahan Jurangmangu Timur, Pondok Aren, Tangerang Selatan.

Berdasarkan latar belakang di atas, maka penelitian ini bertujuan untuk : (1) mengetahui karakteristik masyarakat yang mengkonsumsi tempe di Kelurahan Jurangmangu Timur; (2) mengetahui faktor-faktor yang mempengaruhi permintaan tempe di Kelurahan Jurangmangu Timur; dan (3) mengukur besarnya respon masyarakat terhadap perubahan harga tempedi Kelurahan Jurangmangu Timur.

\section{TINJAUAN PUSTAKA}

\section{Tempe}

Tempe adalah makanan yang dibuat dari fermentasi terhadap biji kedelai atau beberapa bahan lain yang menggunakan beberapa jenis kapang Rhizopus, seperti Rhizopus oligosporus, Rh. oryzae, $R h$. stolonifer (kapang roti), atau Rh. arrhizus. Fermentasi ini secara umum dikenal sebagai "ragi tempe". Kapang yang tumbuh pada kedelai menghidrolisis senyawasenyawa kompleks menjadi senyawa sederhana yang mudah dicerna oleh manusia. Tempe kaya akan serat pangan, kalsium, vitamin B dan zat besi. Berbagai macam kandungan dalam tempe mempunyai nilai obat, seperti antibiotika dan antioksidan. Secara umum, tempe 
berwarna putih karena pertumbuhan miselia kapang yang merekatkan biji-biji kedelai sehingga terbentuk tekstur yang memadat.

Tempe banyak dikonsumsi di Indonesia, tetapi sekarang telah mendunia. Kaum vegetarian di seluruh dunia banyak yang telah menggunakan tempe sebagai pengganti daging. Akibatnya sekarang tempe diproduksi di banyak tempat di dunia, tidak hanya di Indonesia. Berbagai penelitian di sejumlah negara, seperti Jerman, Jepang, dan Amerika Serikat. Indonesia juga sekarang berusaha mengembangkan galur (strain) unggul Rhizopus untuk menghasilkan tempe yang lebih cepat, berkualitas, atau memperbaiki kandungan gizi tempe.

Pada zaman pendudukan Jepang di Indonesia, para tawanan perang yang diberi makan tempe terhindar dari disentri dan busung lapar (Astawan, M 2003). Sejumlah penelitian yang diterbitkan pada tahun 1940-an sampai dengan 1960-an juga menyimpulkan bahwa banyak tahanan Perang Dunia II berhasil selamat karena tempe (Shurtleff, W. \& A. Aoyagi, 2001:153). Tempe yang kaya protein telah menyelamatkan kesehatan penduduk Indonesia yang padat dan berpenghasilan relatif rendah (Onghokham, 2000).

\section{Kandungan Gizi Tempe}

Komposisi gizi tempe baik kadar protein, lemak, dan karbohidratnya tidak banyak berubah dibandingkan dengan kedelai. Namun, karena adanya enzim pencernaan yang dihasilkan oleh kapang tempe, maka protein, lemak, dan karbohidrat pada tempe menjadi lebih mudah dicerna, diserap, dan dimanfaatkan tubuh dibandingkan yang terdapat dalam kedelai. Menurut Widianarko (2002), bahwa secara kuantitatif, nilai gizi tempe sedikit lebih rendah dari pada nilai gizi kedelai. Namun secara kualitatif nilai gizi tempe lebih tinggi karena tempe mempunyai nilai cerna yang lebih baik. Hal ini disebabkan kadar protein yang larut dalam air akan meningkat akibat aktivitas enzim proteolitik. Penggunaan tempe sebagai bahan makanan dapat meningkatkan kesehatan masyarakat. Bagi mereka yang memerlukan makanan rendah kalori, bebas kolesterol, tetapi bergizi tinggi, tempe merupakan salah satu bahan makanan yang tepat untuk dimanfaatkan.

\section{Permintaan}

Lukman (2007:18) menyatakan bahwa permintaan (demand) terhadap suatu barang dan jasa dapat didefinisikan sebagai suatu hubungan antara sejumlah barang atau jasa yang diinginkan oleh konsumen untuk dibeli di pasar pada tingkat harga dan waktu tertentu. Dalam menganalisis mengenai permintaan perlu disadari perbedaan antara permintaan dengan jumlah barang yang diminta. Ahli ekonomi mengatakan bahwa permintaan menggambarkan keadaan keseluruhan dari hubungan antara harga dan jumlah permintaan. Sedangkan jumlah barang yang diminta dimaksudkan sebagai banyaknya permintaan pada suatu tingkat harga tertentu. Jadi permintaan merupakan keinginan konsumen untuk membeli suatu barang pada berbagai tingkat harga selama periode waktu tertentu (Firdaus, 2009:69). 
Ritonga (2003:108) menyatakan permintaan adalah jumlah barang atau jasa yang dibeli dalam berbagai situasi dan tingkat harga. Semakin tinggi (mahal) harga, semakin sedikit permintaan. Sebaliknya semakin rendah (murah) harga, semakin banyak permintaan.

Hukum permintaan tidak berlaku mutlak, tetapi bersifat tidak mutlak dan dalam keadan caretis paribus (faktor-faktor lain dianggap tetap). Hukum permintaan berbunyi "apabila harga mengalami penurunan maka jumlah permintaan akan naik/bertambah, dan sebaliknya apabila harga mengalami kenaikan, maka jumlah permintaan akan turun/berkurang”. Hukum permintaan berbanding terbalik dengan harga (Suprayitno, 2008).

\section{Elastisitas Permintaan}

Elastisitas merupakan suatu indeks (bilangan) yang menggambarkan hubungan kuantitatif antara variabel dependen dengan variabel independen, misalnya antara jumlah barang yang diminta dengan harga barang tersebut. Dengan demikian elastisitas dapat didefinisikan sebagai persentase perubahan variabel dependen sebagai akibat perubahan variabel independen sebesar satu persen. Apabila definisi ini diterapkan pada kasus permintaan, definisi elastisitas permintaan akan berbunyi sebagai berikut: persentase perubahan jumlah barang yang diminta $(Q)$ sebagai akibat perubahan harga barang tersebut (P) sebesar satu persen. Berdasarkan uraian tersebut, secara umum dapat dikatakan bahwa elastisitas adalah bilangan yang menggambarkan hubungan sebab akibat antara variabel independen dengan variabel dependen (Suprayitno, 2008:131).

Tidak semua faktor yang mempengaruhi perubahan permintaan atau penawaran dapat diukur (Firdaus, 2009:77). Faktor-faktor yang mempengaruhi permintaan yang biasa diukur antara lain: harga barang yang bersangkutan, harga barang lain yang berkaitan, dan pendapatan konsumen. Oleh karana itu, elastisitas permintaan dibagi tiga, yaitu:

1. elastisitas harga dari permintaan (price elasticity of demand), sering disebut elastisitas harga;

2. elastisitas silang dari permintaan (cross elastisity of demand), sering disebut elastisitas silang;

3. elastisitas pendapatan dari permintaan (income elastisity of demand), sering disebut elastisitas pendapatan.

\section{METODE PENELITIAN}

\section{Lokasi dan Waktu Penelitian}

Penelitian ini dilaksanakan di Kelurahan Jurangmangu Timur Kecamatan Pondok Aren Kota Tangerang Selatan. Pengumpulan data untuk penelitian ini dilaksanakan mulai bulan Oktober 2013 sampai November 2013.

\section{Jenis dan Sumber Data}

Data yang digunakan dalam penelitian ini berupa data primer dan data sekunder. Data primer diperoleh melalui 
penyebaran kuisioner kepada masyarakat kelurahan Jurangmangu Timur. Data sekunder diperoleh dari pemerintah daerah setempat serta studi pustaka yaitu dengan mencari literatur-literatur seperti; jurnal, buku-buku yang relevan dan artikel yang berhubungan dengan penelitian.

\section{Metode Peng1ambilan Sample}

Metode pengambilan sampel yang digunakan dalam penelitian ini yaitu purposive random sampling atau pengambilan sampel acak secara sengaja di kelurahan Jurangmangu Timur. Responden yang diambil dalam penelitian ini yaitu jumlah KK dari salah satu RW di daerah perkampungan dengan jumlah $\mathrm{KK}$ terbanyak yaitu RW 004 dengan jumlah KK sebesar 1975 KK. Adapun untuk menentukan besarnya sampel menggunakan rumus dari Taro Yamane atau Slovin dengan tingkat kesalahan 10\%, yaitu :

$$
n=\frac{N}{N d^{2}+1}
$$

\section{Dimana :}

$\mathrm{n} \quad=$ Jumlah sampel

$\mathrm{N} \quad=$ Jumlah populasi

$\mathrm{d}^{2} \quad=$ Persentase kesalahan sampel, dalam penelitian ini $10 \%$

Penghitungan jumlah sampel:

$n=\frac{1975}{1975(0,1)^{2}+1}=95,18=95$ responden

Berdasarkan hasil penghitungan dengan menggunakan rumus Slovin, diperoleh jumlah sampel sebanyak 95 responden.

\section{Metode Pengolahan Data}

Dalam pengolahan data digunakan analisis kualitatif dan analisis kuantitatif. Analisis kualitatif digunakan untuk mendeskriptifkan karakteristik responden dan pola konsumsi masyarakat yang ada di wilayah kelurahan Jurangmangu Timur. Metode analisis kualitatif dengan tabulasi sederhana ditujukan untuk memberikan informasi mengenai karakteristik responden dan permintaan tempe pada konsumen rumah tangga di kelurahan Jurangmangu Timur. Karakteristik responden terdiri dari umur, jenis kelamin, pendidikan, pekerjaan, jumlah anggota keluarga, pendapatan.

Alat yang akan digunakan dalam analisis kuantitatif pada penelitian ini adalah dengan bantuan komputer menggunakan program Statistical Product and Service Solution (SPSS). Data yang diperoleh diolah kemudian dilakukan analisis dengan metode regresi linier berganda dan perhitungan elastisitas. Analisis regresi linier berganda digunakan untuk menganalisis pengaruh lebih dari satu variabel independen terhadap variabel dependen. Model persamaan regresi linier berganda untuk permintaan tempe adalah sebagai berikut:

$\mathrm{Y}=\mathrm{a}_{0}+\mathrm{b}_{1} \mathrm{X}_{1}+\mathrm{b}_{2} \mathrm{X}_{2}+\mathrm{b}_{3} \mathrm{X}_{3}+\mathrm{b}_{4} \mathrm{X}_{4}+\mathrm{b}_{5} \mathrm{X}_{5}+$ 


$$
\begin{aligned}
& \text { Keterangan : } \\
& \mathrm{Y} \quad=\text { Permintaan tempe (kg/bulan) } \\
& \mathrm{a} \quad=\text { Konstanta } \\
& \mathrm{b} \quad=\text { Koefisien regresi } \\
& \mathrm{X}_{1} \quad=\text { Harga tempe }(\mathrm{Rp} / \mathrm{kg}) \\
& \mathrm{X}_{2} \quad=\text { Harga tahu }(\mathrm{Rp} / \mathrm{kg}) \\
& \mathrm{X}_{3} \quad=\text { Harga telur }(\mathrm{Rp} / \mathrm{kg}) \\
& \mathrm{X}_{4} \quad=\text { Jumlah anggota } \mathrm{keluarga}(\text { orang}) \\
& \mathrm{X}_{5} \quad=\text { Pendapatan keluarga (Rp/bulan) } \\
& ? \quad \text { = galat atau residu }
\end{aligned}
$$

Untuk memvalidasi bentuk persamaan regresi linear berganda bentuk logaritma natural di atas perlu dilakukan uji statistik, yaitu Uji t-Statistik, Uji F-Statistik, dan uji koefisien determinasi $\left(\mathrm{R}^{2}\right)$. Untuk melihat respon masyarakat terhadap perubahan harga tempe akan diolah dengan menggunakan analisis elastisitas. Elastisitas permintaan terhadap harga tempe menjelaskan perbandingan antara persentase perubahan jumlah barang yang diminta dengan persentase perubahan harga.

\section{HASIL PENELITIAN}

\section{Karakteristik Responden}

Karakteristik masyarakat di kelurahan Jurangmangu Timur terdiri dari jenis kelamin laki-laki sebanyak 10.52\% dan perempuan $89.47 \%$, dengan tingkat umur antara 45-57 sebanyak 41.05\%, pada tingkat pendidikan terbanyak adalah SMA sebanyak 38.95\%, berdasarkan tingkat pekerjaan didominasi oleh ibu rumah tangga sebanyak $68.43 \%$, dengan jumlah anggota keluarga antara 4-6 sebanyak $62.10 \%$, dan kemudian dilihat dari tingkat pendapatannya antara 2.200.000-3.800.000 sebanyak $40 \%$.

\section{Faktor-faktor yang Mempengaruhi permintaan Tempe}

Fungsi permintaan tempe di kelurahan Jurangmangu Timur menggunakan persamaan regresi linear berganda bentuk logaritma natural dalam pengolahannya. Untuk pembahasan permintaan tempe di kelurahaan Jurangmangu Timur dapat dilihat pada tabel 10 berikut ini.

Tabel 1 Hasil Dugaan Pengaruh Harga Tempe, Tahu, Telur, dan Jumlah Anggota Keluarga, serta Pendapatan Keluarga Terhadap Permintaan Tempe di Kelurahan Jurangmangu Timur

\begin{tabular}{lccc}
\hline \multicolumn{1}{c}{ Variabel } & Koef. & $\mathrm{T}_{\text {hit }}$ & Sig \\
\hline Konstanta & -9.927 & -33.143 & 0.000 \\
Harga Tempe & 0.970 & 49.232 & 0.000 \\
Harga Tahu & 0.023 & 1.324 & 0.189 \\
$\begin{array}{l}\text { Harga Telur } \\
\text { Jumlah Anggota }\end{array}$ & -0.005 & -0.452 & 0.653 \\
Keluarga & 0.005 & 0.210 & 0.834
\end{tabular}


Pendapatan

Keluarga

0.027

1.490

0.140

\begin{tabular}{ll}
\hline Adj $R^{2}$ & 0,985 \\
\hline$F_{\text {hit }}$ & 1239.4
\end{tabular}

Sumber : Data Primer, 2013 (Diolah)

Dari persamaan regresi tersebut, diperoleh nilai konstanta sebesar -9.927. Angka tersebut berarti bahwa permintaan tempe akan bernilai -9.927 apabila faktor lain sama dengan nol. Dengan kata lain permintaan tempe akan berada pada tingkat -9.927 jika tidak ada aktifitas konsumsi jenis lauk lain.

Untuk harga tempe $\left(\mathrm{X}_{1}\right)$ dihasilkan koefisien bernilai positif sebesar 0.970 . Tanda positif ini menunjukan hubungan yang berlawanan antara harga tempe dengan jumlah permintaan tempe. Dengan kata lain jika ada kenaikan harga tempe maka akan terjadi peningkatan pernintaan tempe sebesar $0.970 \mathrm{~kg}$. Hal ini dikarenakan kenaikan harga tempe tidak akan setinggi kenaikan pada harga telur.

Koefisien regresi untuk harga telur $\left(\mathrm{X}_{2}\right)$ bernilai positif sebesar 0.023 . Tanda positif ini menunjukan pengaruh yang searah antara harga tahu dengan permintaan tempe. Artinya jika harga tahu naik, maka akan ada peningkatan permintaan tempe sebesar $0.023 \mathrm{~kg}$. hal ini berarti bahwa tahu merupakan barang substitusi dari tempe. koefisien regresi untuk harga telur $\left(\mathrm{X}_{3}\right)$ menunjukan nilai negatif sebesar 0.005 . Artinya jika harga telur naik maka akan menaikan permintaan tempe sebesar 0.005 $\mathrm{kg}$.

Koefisien regresi untuk jumlah anggota keluarga $\left(\mathrm{X}_{4}\right)$ bernilai positif sebesar 0.005. Tanda positif ini menunjukan pengaruh yang searah antara jumlah anggota keluarga dengan permintaan tempe. Artinya jika ada penambahan satu orang anggota keluarga maka akan ada peningkatan permintaan tempe sebesar $0.005 \mathrm{~kg}$. Hal ini menunjukan bahwa semakin besar jumlah anggota keluarga maka semakin besar juga jumlah permintaan akan tempe.

Koefisien regresi untuk pendapatan keluarga (X5) bernilai positif sebesar 0.027 . Angka ini menunjukan pengaruh yang searah antara pendapatan keluarga dengan permintaan tempe. Artinya jika terjadi kenaikan pendapatan sebesar Rp. 1 maka akan mengakibatkan bertambahnya permintaan tempe sebesar 0.027

\section{Uji t}

Hasil analisis uji - $t$ dapat dilihat pada Tabel 19 di atas.Taraf signifikasi 0.1 dan $\mathrm{DK}=\mathrm{n}-\mathrm{k}=95-6=89$ dari ketentuan tersebut diperoleh angka $\mathrm{t}$ tabel 1.291. berdasarkan kriteria penerimaan atau penolakan hipotesis dengan tingkat kepercayaan $90 \%$ adalah sebagai berikut :

Ho : Tidak ada pengaruh signifikan antara masing-masing variabel independen $(\mathrm{X})$ terhadap variabel dependen $(\mathrm{Y})$

H1 : Ada pengaruh signifikan antara masing-masing variabel independen (X) terhadap variabel dependen $(\mathrm{Y})$ 
A) Variabel harga tempe, yaitu t hitung $>$ t tabel atau $49.232>1.291$ maka Ho ditolak dan $\mathrm{H}_{1}$ diterima, artinya harga tempe mempunyai pengaruh sangat nyata terhadap permintaan tempe di kelurahan Jurangmangu Timur pada taraf kepercayaan 99\%.

B) Variabel harga tahu yaitu $\mathrm{t}$ hitung $>\mathrm{t}$ tabel atau $1.324>1.291$ maka Ho ditolak dan $\mathrm{H}_{1}$ diterima, artinya harga tahu mempunyai pengaruh nyata

terhadap permintaan tempe di kelurahan Jurangmangu Timur pada taraf kepercayaan $90 \%$.

c. Variabel harga telur yaitu $\mathrm{t}$ hitung $<\mathrm{t}$ tabel atau $0.452<1.291$ maka Ho terima dan $\mathrm{H}_{1}$ ditolak, artinya harga telur tidak mempunyai pengaruh nyata terhadap perintaan tempe di kelurahan Jurangmangu Timur pada taraf kepercayaan $90 \%$.

d. Variabel jumlah anggota keluarga, yaitu $\mathrm{t}$ hitung $<\mathrm{t}$ tabel atau $0.210<$ 1,291 maka Ho diterima dan $\mathrm{H}_{1}$ ditolak, artinya jumlah anggota keluarga tidak mempunyai pengaruh yang nyata terhadap permintaan tempe di kelurahaan Jurangmangu Timur pada taraf kepercayaan 90\%.

e. Variabel pendapatan keluarga, yaitu $\mathrm{t}$ hitung $>\mathrm{t}$ tabel atau $1.490>1.291$ maka Ho ditolak dan $\mathrm{H}_{1}$ diterima, pendapatan keluarga mempunyai pengaruh nyata teradap permintaan tempe di kelurahan Jurangmangu Timur pada taraf kepercayaan $90 \%$.

\section{Uji F}

Hasil analisis uji $\mathrm{F}$ dapat dilihat pada tabel 19 di atas. Berdasarkan tabel di atas, dapat diketahui bahwa nilai signifikasi sebesar 0.000 dan lebih kecil dari $\alpha=0,1$. Maka $\mathrm{H}_{0}$ ditolak dan $\mathrm{H}_{1}$ diterima, yang artinya variabel-variabel bebas yang diamati dengan tingkat kepercayaan 90\% yaitu harga tempe, harga tahu, harga telur, jumlah anggota keluarga dan pendapatan keluarga secara bersama-sama berpengaruh nyata terhadap permintaan tempe di kelurahan Jurangmangu Timur.

\section{Uji Determinasi}

Berdasarkan tabel 19 di atas, nilai koefisien determinasi menunjukkan seberapa besar variasi perubah variabel tidak bebas yang dapat dijelaskan oleh variasi perubah variabel bebas. Berdasarkan hasil dari analisis diperoleh nilai $\left(\mathrm{R}^{2}\right)$ sebesar 0,985. Hal ini menunjukkan bahwa 98,5\% permintaan tempe di kelurahan Jurangmangu Timur dapat dijelaskan oleh variabel bebas yang digunakan dalam model yaitu harga tempe, harga tahu, harga telur, jumlah anggota keluarga, dan pendapatan keluarga. Sedangkan sisanya sebesar $1.5 \%$ dijelaskan oleh variabel lain di luar model ini.

\section{Elastisitas Permintaan Tempe di Kelurahan Jurangmangu Timur}

Untuk mengetahui nilai elastisitas dari masing-masing variabel yang mempengaruhi permintaan tempe di kelurahan Jurangmangu Timur dapat 
diketahui dari nilai koefisien regresi masing-masing variabel penduganya. Karena salah satu ciri dari model regresi logaritma berganda adalah nilai koefisien regresi dapat menunjukkan nilai elastisitasnya. Berikut ini adalah penjelasan elastisitas permintaan tempe di kelurahan Jurangmangu Timur yang diadopsi dari tabel, dapat dilihat sebagai berikut ini.

Tabel 20 Nilai Elastisitas Permintaan tempe di Kelurahan Jurangmangu Timur

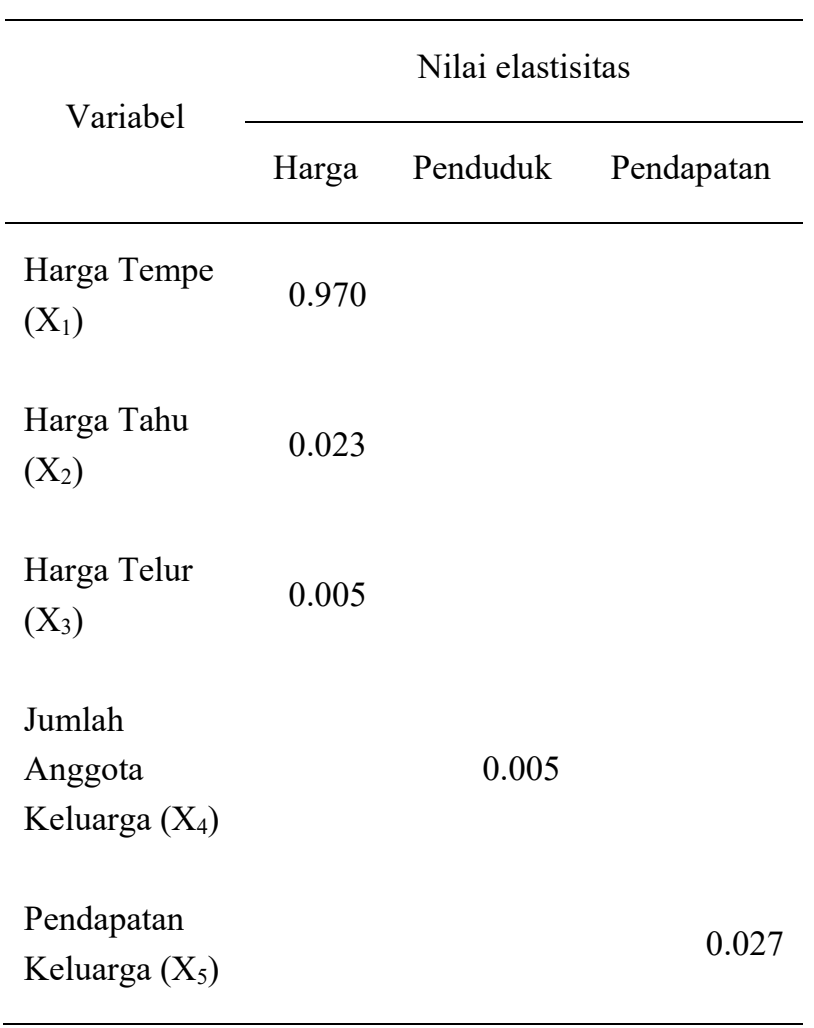

Sumber : Data Primer, 2013 (Diolah).

Hasil analisis elastisitas harga (e) diketahui besarnya elastisitas harga tempe sebesar 0.970. artinya jika harga tempe naik 1 satuan maka akan menaikan jumlah permintaan tempe sebesar $0.970 \mathrm{~kg}$. Permintaan tempe bersifat inelastis karena nilai koefisien elastisitasnya $0.970<1$.
Hasil analisis elastisitas silang dari harga tahu terhadap permintaan tempe didapat nilai elastisitas sebesar 0.023. Jika harga tahu naik 1 satuan maka permintaan tempe akan meningkat sebesar $0.023 \mathrm{~kg}$. Elastisitas harga tahu bersifat inelastis $(0.023<1)$. Nilai koefisien regresi yang positif menunjukan bahwa tahu merupakan barang substitusi dari tempe.

Hasil analisis elastisitas silang dari harga telur sebesar 0.005 , yang berarti nilai elastisitas harga telur lebih kecil dari 1 $(0.005<1)$, maka elastisitas dari variabel tersebut bersifat inelastis. Koefisien regresi dari harga tempe memiliki tanda negatif, hal ini membuktikan bahwa telur merupakan barang komplementer terhadap tempe.

Hasil analisis elastisitas jumlah penduduk diketahui besarnya elastisitas jumlah anggota keluarga adalah 0.005. Jika terjadi kenaikan jumlah anggota keluarga 1 satuan maka akan mengakibatkan bertambahnya permintaan tempe sebesar $0.005 \mathrm{~kg}$. Nilai elastisitas jumlah anggota keluarga $(0.005<1)$ menunjukkan bahwa elastisitas jumlah anggota keluarga terhadap permintaan tempe di kelurahan Jurangmangu Timur bersifat inelastis. Kenaikan jumlah anggota keluarga di kelurahan Jurangmangu Timur tidak berpengaruh besar terhadap permintaan tempe di kelurahan Jurangmangu Timur.

Hasil analisis elastisitas pendapatan diketahui besarnya elastisitas pendapatan keluarga adalah 0.027. Jika terjadi kenaikan pendapatan sebesar 1 satuan maka akan mengakibatkan bertambahnya permintaan tempe sebesar $0.027 \mathrm{~kg}$. koefisien regresi 
yang didapat pada pendapatan keluarga adalah positif menunjukkan bahwa tempe termasuk barang normal, artinya jumlah tempe yang diminta meningkat apabila pendapatan naik. Akan tetapi karena permintaan tempe bersifat inelastis maka apabila terjadi peningkatan pendapatan maka jumlah tempe yang diminta berubah dengan proporsi yang lebih kecil dari proporsi kenaikan pendapatan.

\section{KESIMPULAN DAN SARAN}

\section{Kesimpulan}

1. Dari hasil pengolahan data yang telah dilakukan pada bab sebelumnya, maka disimpulkan hasil penelitian sebagai berikut 1 . Karakteristik masyarakat di kelurahan Jurangmangu Timur terdiri dari jenis kelamin laki-laki sebanyak $10.52 \%$ dan perempuan $89.47 \%$, dengan tingkat umur antara 45-57 sebanyak $41.05 \%$, pada tingkat pendidikan terbanyak adalah SMA sebanyak $38.95 \%$, berdasarkan tingkat pekerjaan didominasi oleh ibu rumah tangga sebanyak $68.43 \%$, dengan jumlah anggota keluarga antara 4-6 sebanyak $62.10 \%$, dan kemudian dilihat dari tingkat pendapatannya antara 2.200.000-3.800.000 sebanyak 40\%.

2. Hasil analisis uji t didapat bahwa harga tempe di kelurahan Jurangmangu Timur berpengaruh sangat nyata terhadap permintaan tempe pada taraf kepercayaan 99\%, variabel harga tahu, dan pendapatan keluarga berpengaruh nyata terhadap permintaan tempe di kelurahan Jurangmangu Timur pada taraf kepercayaan 90\%, sedangkan harga telur, dan jumlah anggota keluarga tidak berpengaruh nyata terhadap permintaan tempe di kelurahan Jurangmangu Timur pada taraf kepercayaan $90 \%$. Hasil analisis uji $\mathrm{F}$ didapat bahwa koefisien regresi signifikan secara statistik pada tingkat kepercayaan 90\%. Kelima faktor tersebut secara bersama-sama dapat dikatakan berpengaruh terhadap permintaan tempe masyarakat di kelurahan Jurangmangu Timur. Hasil pengujian determinasi didapat bahwa 98.5\% permintaan tempe di kelurahan Jurangmangu Timur dapat dijelaskan oleh seluruh variabel. Sedangkan sisanya sebesar $1.5 \%$ dapat dijelaskan oleh variabel lain.

3. Hasil perhitungan elastisitas harga tempe di dapat sebesar 0.970, artinya tempe bersifat inelastis. Dalam jangka pendek Permintaan tempe bersifat inelastis terhadap semua faktor-faktor yang mempengaruhi permintaan tempe di kelurahaan Jurangmangu Timur yang artinya respon masyarakat terhadap perubahan harga tempe, tahu, telur, jumlah anggota keluarga dan pendapatan keluarga tidak berpengaruh besar terhadap perubahan permintaan tempe di kelurahan Jurangmangu

\section{Saran}

Berdasarkan kesimpulan diatas, dapat diberikan saran sebagai berikut : 
1. Melihat dari hasil perhitungan regresi yang menyatakan bahwa harga tempe sangat berpengaruh nyata terhadap permintaan tempe di kelurahan Jurangmangu Timur, sehingga produsen tempe yang ada dapat meningkatkan kapasitas produksi tempe untuk memenuhi kebutuhan tempa masyarakat di kelurahan Jurangmangu Timur.

2. Penelitian ini membahas mengenai elastisitas permintaan jangka pendek, diharapkan ada penelitian lanjutan mengenai elastisitas permintaan jangka panjang terhadap faktor-faktor harga tempe, tahu, telur, dan jumlah anggota keluarga, serta pendapatan keluarga.

\section{DAFTAR PUSTAKA}

Almatsier, Sunita. Prinsip Dasar Ilmu Gizi. (Jakarta: Gramedia Pustaka Utama, 2009).

Andieka, Ulfa. Analisis Faktor-faktor yang mempengaruhi permintaan tempe di Desa Jombang, Kecamatan Ciputat, kota tangerang Selatan, Provinsi Banten (Skripsi). Universitas Islam Negri Jakarta. 2011

Astawan, M. Tempe: Cegah Penuaan \& Kanker Payudara. (Kompas : 2003)

Astuti, M. History of the Development of Tempe. Di dalam Agranoff, J (editor dan penerjemah), The Complete Handbook of Tempe: The Unique Fermented Soyfood of Indonesia. 1999
BPS.2013. Laporan bulanan Data Sosial Ekonomi 2013.BPS Kota Tangerang Selatan

. 2009. Kecamatan Pondok Aren Dalam Anggka 2009. BPS Kota Tangerang Selatan.

. 2010. Kecamatan Pondok Aren Dalam Anggka 2010.BPS Kota Tangerang Selatan.

.2011. Kecamatan Pondok Aren Dalam Angka 2011. BPS Kota Tangerang Selatan. .2012. Kecamatan Pondok Aren Dalam Angka 2012. BPS Kota Tangerang Selatan.

Dwi Sartika, Adetama. Analisis Permintaan Kedelai Indonesia (Skripsi). Universitas Indonesia. 2011

Fatih, Alawi. Faktor-Faktor yang Berhubungan dengan Konsumsi Tempe pada Remaja di SMUN 1 Slawi dan SMUN 1 Tegal (skripsi).IPB. 2003

Firdaus, Muhammad. Manajemen Agribisnis. (Jakarta: Bumi Aksara, 2009).

Ghozali, Imam. Aplikasi Multivariate Dengan Program SPSS. (Semarang: Badan Penerbit Universitas Diponegoro, 2006)

Lukman. Pengantar Teori Mikro Ekonomi. (Jakarta : UIN Jakarta Press, 2007).

Noertjahyo, J A. Dari Ladang Sampai Kabinet Menggugat Nasib Petani. (Jakarta: Penerbit Buku Kompas, 
2005).

Onghokham, Tempe: Sumbangan Jawa untuk Dunia. (Kompas : 2001)

Riduwan dan Akdon. Rumus dan Data dalam Analisis Statistika. (Bandung: Alfabeta, 2009).

Ritonga, dkk. Pelajaran Ekonomi Jilid 1. (Jakarta: Erlangga, 2003).

Sarwono, B. Membuat tempe dan oncom. (Jakarta: PT. Penebar Swadaya, 2002).

Soeharjo, A dan Dahlan Patong. 1991. Sendi-sendi Pokok Usahatani. IPB. Bogor.

Soekartawi. 1989. Prinsip Dasar Ekonomi Pertanian, Teori dan Aplikasi. Radjawali Press. Jakarta.

Sugiarto, dkk. 2002. Ekonomi Mikro Sebuah Kajian Komprehensif.
Jakarta. PT Gramedia Pustaka Utama.

Sugiyanto.Analisis

Statistika

Social.(malang: Bayu Media Anggota IKAPI)

Sugiyono.Metode Penelitian Kuantitatif Kualitatif dan R\&D. (Bandung:

Alfabeta, 2009)

Umar, Husein. Riset Pemasaran dan Perilaku Konsumen Cetakan Keempat.(Jakarta: PT. Gramedia Pustaka Utama, 2005).

Suprayitno, Eko. Ekonomi Mikro Perspektif Islam. (Yogyakarta: UIN-Malang Press, 2008).

Widarjono, Agus. 2007. Ekonometrika teori dan aplikasi. Yogyakarta. Ekonesia

Wijaya, F. 1991. Ekonomika Makro. BPFE-UGM. Yogyakarta.

\footnotetext{
*Alumni Prodi Agribisnis dan ** Dosen Fakultas Sains dan Teknologi UIN Syarif Hidayatullah Jakarta
} 
